\title{
SOME SPECIAL FEATURES OF THE CARIES PREVENTIVE EFFECT OF WATER-FLUORIDATION
}

\author{
O. Backer Dirks, B. Houwink and G. W. Kwant \\ Organisation for Health Research T.N.O., Laboratory of Microbiology, \\ University of Utrecht, Utrecht, Netherlands
}

\begin{abstract}
In March 1953 water-fiuoridation was started in Tiel, the Netherlands. From the caries numbers of three age classes the differences in caries inhibition for the various teeth and for the various tooth surfaces are shown after $5 \frac{1}{2}$ years of fluoridation.

The free smooth surfaces (buccal and labial) show an important caries reduction even if fluoridation started some years after the eruption of the tooth. If waterfluoridation is started 2 or 3 years before eruption the differences are hardly any greater.

Some proximal surfaces show a reasonable caries reduction if water-fluoridation is started shortly after eruption. The degree of protection seems partly determined by the accessibility of the surface for fluoride ions and the condition in the interproximal space. A pre-eruptive period with fluoridated drinking-water increases the effect substantially.

For the occlusal surface, only an insignificant effect was found if fluoridation was started after eruption. If fluoridation is started $2-3$ years before eruption the caries inhibition was still about 50 per cent smaller than for the proximal surfaces. Only in those premolars and second molars which at the start of fluoridation were in an early stage of development, a larger caries inhibition for the occlusal surface was found.

The caries inhibition in the various surfaces seems to be correlated with the degree in which fluorine ions can be built in or absorbed by the enamel of these surfaces.

The degree of caries inhibition found will partly depend upon the methods used for the caries examination. In general, percentages of caries reduction tend to be higher if caries is diagnosed in a more advanced stage.
\end{abstract}

Résumé-En mars 1953, la fluoruration des eaux a été enterprise à Tiel (Pays-Bas). Les différences d'inhibition de la carie par rapport aux dents et aux surfaces dentaires dans trois groupes d'âges différents ont été déterminées après 5 ans et demi.

Une diminution importante des caries de surfaces vestibulaires est notée même sur des dents qui ont subi l'action du fluor plusieurs années après leur éruption. L'action du fluor de l'eau potable, 2 ou 3 ans avant l'éruption, ne semble pas entraîner une diminution plus grande.

Une certaine diminution du nombre des caries proximales est constatée, lorsque la fluoration des eaux débute peu après l'éruption. Le degré de protection semble lié partiellement à l'accessibilité de la surface aux ions fluor et aux conditions éxistant dans l'espace interproximal. Cet effet de l'eau fluorée est notablement augmenté, si l'eau est consommée pendant la période pré-éruptive.

Pour les caries occlusales, seul un effet insignifiant fut observé lorsque la fluoruration est appliquée après éruption. Dans le cas d'une adjonction de fluor à l'eau 2-3 ans avant l'éruption, l'inhibition des caries est encore environ de 50 pour cent moins élevée que pour les surfaces proximales. Ce n'est qu'au niveau des prémolaires et secondes molaires, qui se trouvaicnt à un stade peu avancé de dévcloppement, au moment du début de la fluoration, qu'une inhibition plus prononcée des caries occlusales fut observée. 
L'inhibition de la carie des différentes surfaces dentaires semble en rapport avec le degré d'intégration ou d'absorption des ions fluor au niveau de l'émail de ces surfaces.

Le degré d'inhibition de la carie dépend partiellement des méthodes utilisées pour les examens des caries. En général les pourcentages de réduction ont tendance à devenir plus élevés, lorsque la carie est diagnostiquée à un stade plus avancé.

\begin{abstract}
Zusammenfassung-Seit März 1953 ist das Wasser von Tiel (Niederland) fluoridiert. An Hand der Kariesdaten von drei Altersklassen wurden nach $5 \frac{1}{2}$ Jahre Trinkwasserfluoridierung die unterschiedlichen Karieshemmungen auf die einzelnen Zahnflächen gezeigt.

Es stellte sich heraus, dass die Karieshemmung anscheinend korreliert ist mit dem Masse in dem Fluorionen in den Schmelz der bestimmten Flächen eingebaut oder absorbiert werden können. Diese Möglichkeit der Aufnahme von Fluorionen ist öfters ungleich für die einzelnen Flächen desselben Zahnes.

Es wurde gezeigt, dass der zahlenmässige Ausdruck der Karieshemmung abhängig ist von der Untersuchungsmethodik. Zahlenmässig wird die Karieshemmung desto grösser scin, umso später dic Diagnose "Karies" gestellt wird.
\end{abstract}

\title{
INTRODUCTION
}

IN MARCH, 1953, a pilot fluoridation scheme was started in the Netherlands, in order to determine the caries preventive effect of water-fluoridation under Dutch living conditions. The town of Tiel was fluoridated $(1 \cdot 1$ p.p.m. F) and the nearby town of Culemborg served as fluoride-free control $(0 \cdot 1$ p.p.m. F).

The favourable effect of water-fluoridation on the dental caries experience in Tiel has been described elsewhere (HEalTh CouncIL, 1960). In this communication attention will be paid to the differences in effect for the various surfaces of the teeth as manifest after $5 \frac{1}{2}$ years of fluoridation.

\section{MATERIAL AND METHODS}

To demonstrate the effect of fluoridation on caries initiation and progression, the caries data of three groups of children are selected, i.e. children born in 1945, 1946 and 1949. At the beginning of fluoridation their mean age was respectively $7 \frac{3}{4}, 6 \frac{3}{4}$ and $3 \frac{3}{4}$ years.

Each age class consists of about fifty girls and fifty boys selected at random. All caries numbers to be presented are the mean values of the mean for the girls and the mean for the boys.

The methods used in the caries examination have been published elsewhere (Backer Dirks, van Amerongen and Winkler, 1951; Backer Dirks and KWANT, 1954; BaCker Dirks, KWANT and KlaAssen, 1957). These methods aim at a careful and standardized caries examination. Special methods were used to prevent a shift in diagnostic standards from year to year. The examination comprised two parts:

1. An X-ray examination for the evaluation of the lesions of the proximal surfaces.

2. A physical examination for the pit and fissure lesions of molars and premolars and for the lesions of the smooth free surfaces (buccal and labial only).

Every examination is carried out twice, independently by two dentists. The standard error of the caries obser ation proved to be one tenth of the sampling error of the 
group. The $\mathrm{X}$-rays of fluoride and control group were mixed and a blind evaluation was made. In order to avoid a bias in the physical examination each half week the examination is shifted to the other town. The time devoted to the examination of an $\mathrm{X}$-ray set is $6-10 \mathrm{~min}$, and to the physical examination $5-20 \mathrm{~min}$, depending upon the age of the children.

Caries numbers are either presented as all lesions observed or as the number of lesions with macroscopic cavitation in the physical examination and dentine involvement in the X-ray examination.

\section{RESULTS}

The differences in the kind of caries diagnoses between the proximal surfaces (X-ray examination) and smooth free surfaces (physical examination) make it impossible to add these numbers. The structural differences in occlusal surfaces and smooth surfaces also dictate a separate treatment of these numbers.

Particularly in a caries preventive study, separate treatment of the various kinds of surfaces is necessary as these may be influenced in different ways.

Table 1. Cavities Per Child, SeParately for the Various Kinds Of SURfaces, 1958

\begin{tabular}{|c|c|c|c|c|c|c|c|}
\hline \multirow[b]{2}{*}{$\begin{array}{c}\text { Year } \\
\text { of } \\
\text { birth }\end{array}$} & \multirow[b]{2}{*}{$\begin{array}{c}\text { Age at start } \\
\text { of fluoridation } \\
\text { (years) }\end{array}$} & \multirow[b]{2}{*}{ Age } & \multirow[b]{2}{*}{ Town } & \multicolumn{4}{|c|}{ Number of cavities per child } \\
\hline & & & & $\begin{array}{l}\text { Proximal } \\
\text { (Inc. } \\
\text { included) }\end{array}$ & $\begin{array}{c}\text { Pits } \\
\text { and } \\
\text { fissures }\end{array}$ & $\begin{array}{c}\text { Buccal } \\
\text { and } \\
\text { labial }\end{array}$ & $\begin{array}{l}\text { Incisors } \\
\text { proximal }\end{array}$ \\
\hline 1945 & $7 \frac{3}{4}$ & 13 & $\begin{array}{l}\text { Culemborg } \\
\text { Tiel }\end{array}$ & $\begin{array}{l}5 \cdot 2 \\
3 \cdot 6\end{array}$ & $\begin{array}{r}11.4 \\
9.6\end{array}$ & $\begin{array}{l}1.0 \\
0.4\end{array}$ & $\begin{array}{l}1.6 \\
1.0\end{array}$ \\
\hline 1946 & 69 & 12 & $\begin{array}{c}\text { Culemborg } \\
\text { Tiel }\end{array}$ & $\begin{array}{l}3 \cdot 9 \\
2 \cdot 0\end{array}$ & $\begin{array}{r}10 \cdot 0 \\
7.8\end{array}$ & $\begin{array}{l}0 \cdot 9 \\
0 \cdot 3\end{array}$ & $\begin{array}{l}1.7 \\
0.6\end{array}$ \\
\hline 1949 & $3 \frac{3}{4}$ & 9 & $\begin{array}{c}\text { Culemborg } \\
\text { Tiel }\end{array}$ & $\begin{array}{l}0.9 \\
0 \cdot 3\end{array}$ & $\begin{array}{l}5 \cdot 7 \\
4 \cdot 1\end{array}$ & $\begin{array}{l}0 \cdot 5 \\
0 \cdot 2\end{array}$ & $\begin{array}{l}0.25 \\
0.05\end{array}$ \\
\hline
\end{tabular}

In Table 1 the number of attacked surfaces per child is shown for the three types of surfaces separately and in Table 2 the percentage reduction in the number of cavities in the fluoride town.

Except for the second molar, all teeth of the 1945 and 1946 class were already calcified or even erupted at the start of fluoridation.

The caries reduction in the huccal and labial surfaces is larger than in the proximal surfaces, whereas the pit and fissures show the smallest effect.

As the teeth, even in one age class, were not in the same developmental stage at the start of fluoridation, the numbers given are in fact not very well comparable. For this reason Table 3 shows the caries numbers, only for the first molar, in the 1946 and 1949 class.

In both groups the buccal surfaces exhibit the largest effect, followed by the proximal surfaces, whereas the pits and fissures show the smallest effect. 
Table 2. Percentage less cavities in Tiel as compared to Culemborg, 1958

\begin{tabular}{c|c|c|c|c|c|c}
\hline $\begin{array}{c}\text { Year } \\
\text { of } \\
\text { birth }\end{array}$ & $\begin{array}{c}\text { Age at start } \\
\text { of water F } \\
\text { (years) }\end{array}$ & $\begin{array}{c}\text { Age } \\
\text { (years) }\end{array}$ & $\begin{array}{c}\text { Percentage less cavities in Tiel } \\
\text { (Inc. included) }\end{array}$ & $\begin{array}{c}\text { Pits and } \\
\text { fissures }\end{array}$ & $\begin{array}{c}\text { Buccal or } \\
\text { labial }\end{array}$ & $\begin{array}{c}\text { Incisors } \\
\text { proximal }\end{array}$ \\
\hline 1945 & 73 & 13 & 31 & $16^{*}$ & 54 & 38 \\
1946 & $6 \frac{3}{4}$ & 12 & 49 & 22 & 71 & 63 \\
1949 & 33 & 96 & 28 & 66 & $80^{*}$ \\
\hline
\end{tabular}

* Difference not significant at the $P=0.01$ level.

TABLE 3

\begin{tabular}{l|c|c|c|c}
\hline & \multicolumn{4}{|c|}{ Number of cavities per child } \\
\cline { 2 - 4 } & $\begin{array}{c}\text { Pits } \\
\text { and } \\
\text { fissures* }\end{array}$ & $\begin{array}{c}\text { Mesial } \\
\text { surface }\end{array}$ & $\begin{array}{c}\text { Distal } \\
\text { surface }\end{array}$ & $\begin{array}{c}\text { Smooth } \\
\text { buccal } \\
\text { surface }\end{array}$ \\
\hline Age 12 (1946) & & & & \\
Culemborg & 6.7 & 1.5 & 1.1 & 0.40 \\
Tiel & 6.0 & 1.3 & 0.8 & 0.16 \\
$\%$ difference & $10 \dagger$ & $13 \dagger$ & 27 & 60 \\
Age 9 (1949) & 5.8 & 0.8 & 0.4 & 0.41 \\
Culemborg & 4.1 & 0.4 & 0.2 & 0.14 \\
Tiel \\
$\%$ difference
\end{tabular}

* In the maxillary molars the two fissures (mesio-buccal and disto-lingual) and in the mandibular the occlusal fissure and the buccal pit are counted separately.

$\dagger$ Difference not significant at the $P=0.01$ level.

The first molar of the children born in 1946 had already erupted at the start of fluoridation, the first molar of the 1949 class was calcified but only erupted 2 years later.

In the buccal surface there is for both age classes an important caries inhibition of about the same magnitude. The proximal surfaces of the 1949 class show both about the same caries inhibition, whereas the reduction in the 1946 class is not only smaller but also differs significantly for the mesial and distal surface. Only the occlusal surface of the molars of the children born in 1949 exhibit a significant caries inhibition.

The tables presented up to now dealt with cavities only (or dentinal lesions on the X-ray.

Table 4 gives for the proximal surfaces the number of lesions per child in two caries grades. 
Table 4. Proximal lesions per child, 1958

\begin{tabular}{l|c|c|c|c|c|c}
\hline Age (years) & \multicolumn{2}{|c|}{13} & \multicolumn{2}{c|}{12} & \multicolumn{2}{c}{9} \\
Age at start of F & \multicolumn{2}{|c|}{$7 \frac{3}{4}$} & \multicolumn{2}{c|}{$6 \frac{3}{3}$} \\
\hline Caries grade & I-V & II-V & I-V & II-V & I-V & II-V \\
\hline Culemborg & $15 \cdot 8$ & $5 \cdot 2$ & $12 \cdot 1$ & $3 \cdot 9$ & 3.5 & 0.9 \\
Tiel & $12 \cdot 5$ & $3 \cdot 6$ & $\begin{array}{c}8 \cdot 7 \\
28\end{array}$ & $\begin{array}{c}2 \cdot 0 \\
49\end{array}$ & $\begin{array}{c}1.9 \\
46\end{array}$ & $\begin{array}{c}0 \cdot 3 \\
66\end{array}$ \\
\hline
\end{tabular}

$\mathrm{I}-\mathrm{V}=$ all lesions; II-V=lesions with dentine involvement.

The percentage difference in cavities for each age class is much larger than for the total number of lesions. The same holds true for the fissure lesions, and the smooth surface lesions. The important difference in the number of dentinal lesions as compared with the total number of lesions diagnosed, is striking. The difference between the two numbers are the numbers of lesions confined to the enamel. In Culemborg there are twice as many enamel lesions as dentinal lesions, in Tiel three times more.

\section{DISCUSSION}

RUSSELL and WHITE (1959) found in a similar study a correlation between the observed caries inhibition and the length of fluoride exposure prior to eruption. Although in our material the same correlation is noted, the various surfaces of one tooth may show large differences in caries inhibition.

These differences in effect for the various surfaces point to the fact that a tooth index (e.g. DMF teeth) is in these cases less appropriate to describe caries inhibition than a surface index.

As caries inhibition seems to be caused by the degree of fluoride uptake by the enamel, we tried to understand the differences in caries inhibition of the various surfaces as an expression of a difference in fluoride uptake.

Three stages in which fluoride may enter the enamel can be differentiated. The first stage is the period of matrix formation and calcification, the second stage the period of pre-eruptive maturation and the third stage the post-eruptive period.

If fluoridation starts after eruption of a tooth, it seems that only those surfaces which are readily accessible to fluoride ions will show an increased caries resistance (Tables 2 and 3), i.e. the free smooth surfaces (buccal, labial) and those proximal surfaces where the diffusion route is short and convection current good (proximal surfaces of incisors). The distal surface of the first molar is at eruption also a free accessible surface as there is no adjacent tooth at that time. The conditions for fluoride adsorption on the mesial surface are especially poor. Directly after cruption this surface comes into contact with the distal surface of the second deciduous molar. Again the generally cariogenic milieu of this interproximal area will harm the physicochemical conditions conducive to the uptake of ions. Also in the deep fissures and pits the uptake of ions will be difficult (Table 3, 1946 class). 
During the pre-eruptive maturation period all smooth surfaces will incorporate fluoride ions in their outer layers, which results in an increased caries resistance. The smaller caries reduction in the occlusal surface of the first molar of the children born in 1949 ( $3 \frac{3}{4}$ years before the start of fluoridation) as compared with the caries reduction in the other surfaces, may be explained by the less favourable physical conditions (deep fissures) for the uptake of fluoride ions (Table 3). If fluoridation is started during matrix formation and calcification, all surfaces may acquire fluoride in equal amounts in this period; a different amount, however, during the pre-eruptive is started early, a smaller effect in the occlusal, than in the other surfaces. The fluoridation period in Tiel has not been sufficiently long to study enough teeth calcified during fluoridation. Especially for the fissures of first permanent molar and deciduous molars, one would expect a decreased inhibition, as these teeth are formed and partly calcified in a period with a small fluoride uptake by the foetus and the young child (pregnancy and lactation).

The smaller effect of fluoridation upon the number of all lesions as compared with the number of dentinal lesions proves that caries initiation as well as the rate of caries progression is reduced (Table 4). Also in those surfaces which received their fluoride only after eruption the rate of caries progression is markedly reduced.

The percentage of carjes inhibition of enamel lesions in comparison with the inhibition of dentinal lesions points to the fact that every less extensive caries examination, in which only real cavities are diagnosed, will tend to show higher values for the caries inhibition (HAYes, MCCAUley and ARNOLD, 1956).

\section{REFERENCES}

Health Council. 1960. Report of the Committee on fluoride of the Health Council, the Netherlands, June 1960. (Dutch text).

Backer Dirks, O., van Amerongen, J. and Winkler, K. C. 1951. A reproducible method for caries evaluation. J. dent. Res. 30, 346-359.

BACKER DIRKS, O. and KWANT, G. W. 1954. A reproducible method for caries evaluation-IV. Tijdschr. Tandheelk. 61, 891-904.

Backer Dirks, O., Kwant, G. W. and Klaassen, C. B. 1957. A reproducible method for caries evaluation-V. Pit and fissure caries of molars and prae-molars. Tijdschr. Tandheelk. 64, 77-85.

Russell, A. L. and WHITE, C. L. 1959. Dental caries in Maryland children after 5 years of fluoridation. Publ. Hlth Rep., Wash. 74, 289-295.

Hayes, R. L., McCauley, H. B. and ARnOld, F. A. 1956. Clinical and roentgenographic examinations for dental caries in Grand Rapids, Mich. Publ. Hlth Rep., Wash. 71, 1228-1236. 